\title{
CORRECTION
}

\section{Correction to: Impact on mortality of prompt admission to critical care for deteriorating ward patients: an instrumental variable analysis using critical care bed strain}

\author{
Steve Harris ${ }^{*^{*}} \mathbb{0}$, Mervyn Singer ${ }^{2}$, Colin Sanderson ${ }^{3}$, Richard Grieve ${ }^{3}$, David Harrison ${ }^{4}$ and Kathryn Rowan ${ }^{4}$
}

(c) 2018 The Author(s)

\section{Correction to: Intensive Care Med} https://doi.org/10.1007/s00134-018-5148-2

This article was originally published under a CC BY-NC 4.0 license, but has now been made available under a $\mathrm{CC}$ BY 4.0 license. The PDF and HTML versions of the paper have been modified accordingly.

\section{Open access}

This article is distributed under the terms of the Creative Commons Attribution 4.0 International License (http:// creativecommons.org/licenses/by/4.0/), which permits unrestricted use, distribution, and reproduction in any medium, provided you give appropriate credit to the original author(s) and the source, provide a link to the Creative Commons license, and indicate if changes were made.

\section{Electronic supplementary material}

The online version of this article (https://doi.org/10.1007/s00134-018-5254-1) contains supplementary material, which is available to authorized users.

\begin{abstract}
Author details
${ }^{1}$ Critical Care Department, University College Hospital London, 235 Euston Road, London NW1 2BU, UK. ${ }^{2}$ Wolfson Institute for Biomedical Research, University College London, The Cruciform Building, Gower Street, London WC1E $6 B$, UK. ${ }^{3}$ Department of Health Services Research and Policy, London School of Hygiene and Tropical Medicine, Keppel Street, London WC1E 7HT, UK.

${ }^{4}$ Intensive Care National Audit and Research Centre, Napier House, 24 High Holborn, London WC1V 6AZ, UK.
\end{abstract}

\section{Open Access}

This article is distributed under the terms of the Creative Commons Attribution 4.0 International License (http://creativecommons.org/licenses/by/4.0/), which permits unrestricted use, distribution, and reproduction in any medium, provided you give appropriate credit to the original author(s) and the source, provide a link to the Creative Commons license, and indicate if changes were made.

Published online: 8 June 2018

\footnotetext{
*Correspondence: doc@steveharris.me
${ }^{1}$ Critical Care Department, University College Hospital London, 235

${ }^{*}$ Correspondence: doc@steveharris.me
${ }^{1}$ Critical Care Department, University College Hospital London, 235 Euston Road, London NW1 2BU, UK

Full author information is available at the end of the article
}

The original article can be found online at https://doi.org/10.1007/s0013 4-018-5148-2. 